\title{
Orthodontic braces come back to bite: a novel presentation of a small bowel volvulus
}

\author{
Talia Shepherd, Adrian Teo, Richard Naunton-Morgan
}

Sir Charles Gairdner Hospital, General Surgery, Nedlands, Western Australia, Australia

Correspondence to Dr Talia Shepherd, talia. shepherd@health.wa.gov.au

Accepted 19 June 2017

\section{DESCRIPTION}

A previously well 30-year-old woman re-presented to the emergency department complaining of worsening central abdominal pain initially colicky at first presentation 2 days earlier. She was tachycardic at 105 and other vital signs were normal. Her abdomen was peritonitic. At initial presentation, she was thought to have biliary colic, even though ultrasound and hepatobiliary iminodiacetic acid scans were normal. She did not have plain abdominal films. Laboratory studies were normal. CT of the abdomen revealed a metallic wire-shaped foreign body at the mesenteric root of a small bowel volvulus (figure 1). The patient underwent an emergency laparotomy which discovered mid-small bowel ischaemia from a band adhesion related to the perforation of a $7 \mathrm{~cm}$ piece of orthodontic wire (figure 2). The wire penetrated through the small bowel and the small bowel mesentery and to another loop of the mid-small bowel. This had formed an axis around which the volvulus developed.

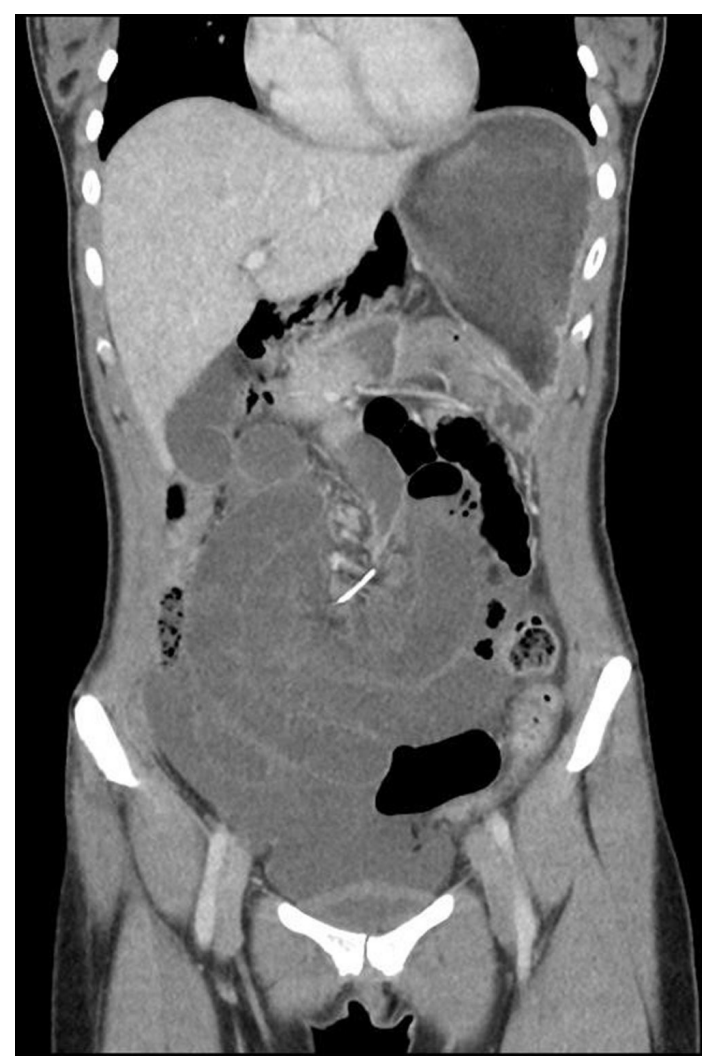

Figure $1 \mathrm{CT}$ image (coronal) of orthodontic wire at the root of the small bowel volvulus.

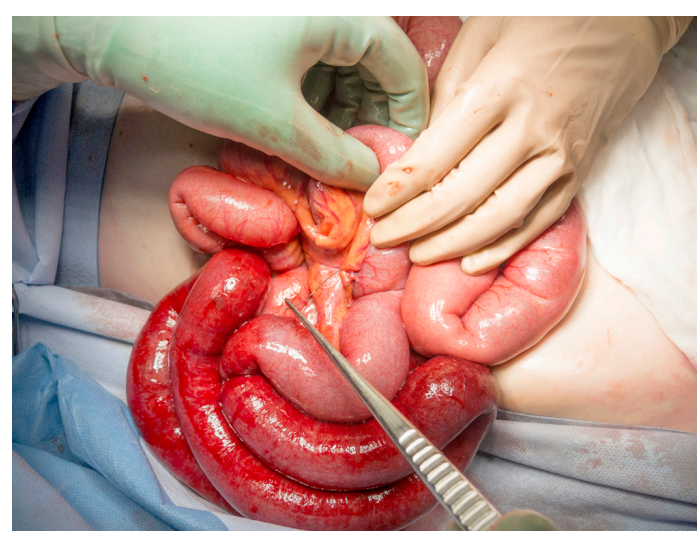

Figure 2 Intraoperative photograph of the orthodontic wire embedded in the small bowel mesentery after the ischaemic bowel was released.

\section{Learning points}

- Foreign body ingestion should be considered as a cause of abdominal pain in patients with no other medical or surgical history.

- Routine plain film of the abdomen is a useful initial investigation and should not be overlooked.

Adhesiolysis was performed but no bowel resected. The patient had not worn orthodontic braces for 10 years and did not recall ingesting the wire or having her braces wire go missing.

Most inert ingested objects, if they pass the cricopharyngeal sphincter, will pass spontaneously. ${ }^{1}$ The most common site for perforation or obstruction is the ileocaecal valve. ${ }^{1}$ The case we describe here is therefore novel in the decade delay in presentation and the clinical sequelae.

Contributors TS: wrote the article. AT and RN-M: contributed to the editing process.

Competing interests None declared.

Patient consent Obtained.

Provenance and peer review Not commissioned; externally peer reviewed.

(c) BMJ Publishing Group Ltd (unless otherwise stated in the text of the article) 2017. All rights reserved. No commercial use is permitted unless otherwise expressly granted.

\section{REFERENCE}

1. Hoseini M, Mostafavi SMS, Rezaei N, et al. Orthodontic Wire Ingestion during treatment: reporting a case and review the management of Foreign Body Ingestion or Aspiration (Emergencies). Case Rep Dent 2013:2013:1-3. 
Copyright 2017 BMJ Publishing Group. All rights reserved. For permission to reuse any of this content visit http://group.bmj.com/group/rights-licensing/permissions.

BMJ Case Report Fellows may re-use this article for personal use and teaching without any further permission.

Become a Fellow of BMJ Case Reports today and you can:

- Submit as many cases as you like

- Enjoy fast sympathetic peer review and rapid publication of accepted articles

Access all the published articles

- Re-use any of the published material for personal use and teaching without further permission

For information on Institutional Fellowships contact consortiasales@bmjgroup.com

Visit casereports.bmj.com for more articles like this and to become a Fellow 